\title{
Extraction of Spore-lytic Enzyme from Clostridium perfringens Spores
}

\author{
By DAVID E. GOMBAS AND RONALD G. LABBE* \\ Food Microbiology Laboratory, Department of Food Science and Nutrition, University of \\ Massachusetts, Amherst, Massachusetts 01003, U.S.A.
}

(Received 10 December 1980; revised 17 February 1981)

\begin{abstract}
Various chemical reagents known to extract spore coat protein were used to extract spore-lytic enzyme (SLE) from intact and germinated spores of Clostridium perfringens. Of the reagents tested, $7.2 \mathrm{M}$-urea plus $10 \%(\mathrm{v} / \mathrm{v})$ mercaptoethanol, $\mathrm{pH} 2 \cdot 85$, solubilized the most SLE activity per mg spores. The quantity of SLE extracted was dependent on the initial $\mathrm{pH}$ of the reagent, with a maximum between $\mathrm{pH} 2.7$ and 3.0 . Germinated spores yielded more SLE than non-germinated spores upon urea/mercaptoethanol extraction. SLE release during spore germination probably utilizes a trigger mechanism not satisfied by germination alone. Significant amounts of SLE were released during germination when spores were suspended in potassium chloride or a complex germinant mixture containing brain-heart infusion, yeast extract and chloramphenicol, but not during germination with sodium nitrite, which non-enzymically lysed the cortical peptidoglycan. Greater solubilization of SLE activity was obtained by urea/mercaptoethanol extraction of spores germinated with nitrite than of spores germinated with either potassium chloride or the complex germinant.
\end{abstract}

\section{INTRODUCTION}

Powell \& Strange (1953) postulated the presence of an enzymic lytic system in bacterial spores and its role during germination. Since then, the spore-lytic enzymes of Bacillus cereus have been isolated and extensively studied by Strange \& Dark (1957), Gould et al. (1966), Warth (1972) and Brown et al. (1975, 1977, 1978). In most cases, this lytic system was found to hydrolyse the peptidoglycan of the spore cortex, resulting in germination-like changes in the spore. Warth (1972) found that B. cereus spores contain four separate cortex-degrading enzymes. Brown et al. (1977) reported that cortex-lytic activities were localized in both the core and in the coat fraction, and these could be isolated separately by particular extraction procedures. Further evidence for the association of cortex-lytic (germination) enzyme with the coat fraction follows from the observation that, in several cases, treatment of dormant spores with reagents which remove spore coat have resulted in a reduced ability of those spores to germinate. This has occurred with, for example, urea/mercaptoethanol (UME) treatment of Bacillus megaterium (Vary, 1973), alkaline dithioerythritol/sodium dodecyl sulphate treatment of B. cereus (Aronson \& Fitz-James, 1976), dithiothreitol/urea or alkaline treatment of Clostridium bifermentans (Wyatt \& Waites, 1974), and alkaline treatment (Duncan et al., 1972) or alkaline dithiothreitol treatment of Clostridium perfringens (Labbe et al., 1978). These observations could be the result of the cortex-lytic enzymes being either solubilized and removed or simply inactivated by the treatments. Indeed, Brown et al. (1978) have extracted and purified a cortex-lytic enzyme from $B$. cereus spores using urea/mercaptoethanol and guanidine/mercaptoethanol. However, it is not clear whether this enzyme plays the only or a major role in germination 
since they were unable to observe germination-like changes in sensitized spores following treatment with this enzyme.

On the other hand, very little has been published on the lytic systems of other bacterial spores. In particular, a similar cortex-lytic enzyme was only recently reported in $C$. perfringens by Ando (1979), who found that spores germinated in the presence of potassium chloride at $\mathrm{pH} 7.0$ exuded an enzyme capable of hydrolysing cortical fragments and causing germination of alkali-treated (coat-altered) spores.

In this study, several of the methods known to extract bacterial spore coats were tested for their ability to extract active spore-lytic enzyme from $C$. perfringens spores.

\section{METHODS}

Organism. Clostridium perfringens NCTC 8798 , Hobbs serotype 9 (H9) was originally obtained from C. Duncan, University of Wisconsin.

Media and sporulation. Spores of $C$. perfringens $\mathrm{H} 9$ were grown and cleaned as described by Franceschini \& Labbe (1979). Final spore suspensions contained less than $1 \%$ vegetative cells, as determined by phase-contrast microscopy.

Preparation of germinated spores. Cleaned spores were suspended in $25 \mathrm{~mm}$-sodium phosphate buffer, $\mathrm{pH} 6.0$, and heated at $75^{\circ} \mathrm{C}$ for $15 \mathrm{~min}$. For spores germinated with nitrite ( $\mathrm{N}$-germinated spores), suspensions were brought to $0.1 \mathrm{M}$-sodium nitrite in the same buffer and a final spore concentration of about $5 \mathrm{mg}$ (initial dry wt) $\mathrm{ml}^{-1}$, and held at $45{ }^{\circ} \mathrm{C}$ for $45 \mathrm{~min}$; at this time microscopic examination showed greater than $95 \%$ phase-dark spores. For 'non-germinated' spores, suspensions were treated similarly but the nitrite was omitted; less than $10 \%$ of these spores became phase-dark. For potassium chloride-germinated spores (K-germinated spores), sodium phosphate buffer and sodium nitrite were replaced by $50 \mathrm{~mm}$-potassium phosphate buffer, $\mathrm{pH} 7 \cdot 0$, and 50 mM-potassium chloride. Spores germinated in a complex medium (CG-germinated spores) were prepared by incubation in a final concentration of $5.0 \%(\mathrm{w} / \mathrm{v})$ brain-heart infusion plus $0.5 \%(\mathrm{w} / \mathrm{v})$ yeast extract plus $30 \mu \mathrm{g}$ chloramphenicol ml-1. Greater than $95 \%$ of the spores germinated by these methods were sensitive to heating at $75^{\circ} \mathrm{C}$ for $15 \mathrm{~min}$.

Enzyme extraction. After germination, spores were pelleted by centrifugation at $3020 \mathrm{~g}$ for $10 \mathrm{~min}$, washed once with cold sterile distilled water, and resuspended in one of the extraction reagents at $5.8 \mathrm{mg}$ (initial dry wt) $\mathrm{ml}^{-1}$. The 'acidic' extraction reagents included $7.2 \mathrm{M}$-urea (U), $3.6 \mathrm{M}$-guanidine. $\mathrm{HCl}(\mathrm{G}), 10 \%(\mathrm{v} / \mathrm{v})$ mercaptoethanol (ME), $50 \mathrm{mM}$-dithiothreitol (DTT), $7.2 \mathrm{M}$-urea plus $10 \%(\mathrm{v} / \mathrm{v})$ mercaptoethanol (UME) and $3.6 \mathrm{M}$-guanidine. $\mathrm{HCl}$ plus $10 \%(\mathrm{v} / \mathrm{v})$ mercaptoethanol (GME). The 'alkaline' reagents included UME, DTT and ME. Spores were extracted at $45{ }^{\circ} \mathrm{C}$ for $90-120 \mathrm{~min}$, except for spores in reagents containing guanidine which were extracted for $60 \mathrm{~min}$ only (see below). After extraction the spores were removed by centrifugation at $3020 \mathrm{~g}$ for $10 \mathrm{~min}$ and the supernatant fluid was dialysed overnight against distilled water at $4{ }^{\circ} \mathrm{C}$ before assaying for enzyme activity and protein concentration. In some experiments enzyme activity was assayed during germination. In these cases, samples were taken at specified intervals, the spores were removed by centrifugation as above, and the supernatant was assayed directly without prior dialysis.

In some cases, spore pellets were re-extracted with acidic UME for $120 \mathrm{~min}$, centrifuged as above, and the re-extracted material was dialysed overnight before assaying for activity and protein.

Enzyme assay. Spore-lytic enzyme (SLE) activity was assayed using spores stripped of their coat protein, as described by Franceschini \& Labbe (1979). These were prepared by treating clean spores with 50 mM-dithiothreitol plus $1 \%(\mathrm{w} / \mathrm{v})$ sodium dodecyl sulphate, $\mathrm{pH} 10 \cdot 0$, at $37^{\circ} \mathrm{C}$ for $2 \mathrm{~h}$ followed by extensive washing with distilled water. Stripped spores were suspended in either 25 mM-sodium phosphate, 25 $\mathrm{mM}$-Tris/maleate or $25 \mathrm{mM}$-maleate buffer, $\mathrm{pH} 6.0$, to a turbidity of 0.4 to 0.5 at $600 \mathrm{~nm}$. Assays were performed at $37^{\circ} \mathrm{C}$ in a Beckman 25 spectrophotometer equipped with a kinetic system. Activity was determined from the linear decrease in turbidity. One unit (U) of activity was defined as a decrease in $A_{600}$ of $0.01 \mathrm{~min}^{-1}$.

In some experiments, cortical fragments, prepared from strain 8798 spores by the method of Hashimoto et al. (1972), were used in place of stripped spores, and the turbidity was monitored at $400 \mathrm{~nm}$.

Protein assay. Protein was assayed by the method of Bradford (1976), using crystalline bovine serum albumin as a standard.

Chemicals. Urea, mercaptoethanol, dithiothreitol, chloramphenicol and bovine serum albumin were obtained from Sigma. Guanidine. $\mathrm{HCl}$ was from Eastman Kodak, sodium nitrite was from J. T. Baker Chemical Co. (Phillipsburg, N.J., U.S.A), and potassium chloride and sodium thioglycollate were from Fisher Scientific (Fairlawn, N.J., U.S.A.). Brain-heart infusion and yeast extract were obtained from Difco. All chemicals were reagent grade. 
Table 1. Extraction of spore-lytic enzyme from non-germinated and nitrite-germinated spores of C. perfringens

\begin{abstract}
Clean spores were heated $\left(75^{\circ} \mathrm{C}, 15 \mathrm{~min}\right)$, then either incubated in sodium phosphate buffer (nongerminated spores) or germinated in sodium nitrite (N-germinated spores) as described in Methods. Spores were washed once in cold distilled water before extraction. Extracted spores were removed by centrifugation and the extracts were dialysed overnight before assaying for protein and SLE activity. Reagents: U, 7.2 M-urea; G, $3.6 \mathrm{M}$-guanidine. $\mathrm{HCl} ; \mathrm{ME}, 10 \%$ (v/v) mercaptoethanol; DTT, 50 mM-dithiothreitol; UME, 7.2 M-urea plus $10 \%(\mathrm{v} / \mathrm{v})$ mercaptoethanol; GME, $3.6 \mathrm{M}$-guanidine. $\mathrm{HCl}$ plus $10 \%(\mathrm{v} / \mathrm{v})$ mercaptoethanol.
\end{abstract}

\begin{tabular}{|c|c|c|c|c|c|c|c|}
\hline \multirow{2}{*}{\multicolumn{2}{|c|}{$\begin{array}{l}\text { Extraction } \\
\text { procedure }\end{array}$}} & \multicolumn{3}{|c|}{ Non-germinated spores } & \multicolumn{3}{|c|}{$\mathrm{N}$-germinated spores } \\
\hline & & \multirow{2}{*}{$\begin{array}{l}\text { Protein } \\
\left(\mathrm{mg} \mathrm{ml}^{-1}\right)\end{array}$} & \multirow{2}{*}{$\begin{array}{l}\text { Activity } \\
\left(\mathrm{U} \mathrm{ml}^{-1}\right)\end{array}$} & \multirow{2}{*}{$\begin{array}{l}\text { Specific } \\
\text { activity } \\
\left(\mathrm{U}^{-1} \mathrm{~m}^{-1}\right)\end{array}$} & \multirow{2}{*}{$\underset{\left(\mathrm{mg} \mathrm{ml}^{-1}\right)}{\text { Protein }}$} & \multirow{2}{*}{$\begin{array}{l}\text { Activity } \\
\left(\mathrm{U} \mathrm{mi}^{-1}\right)\end{array}$} & \multirow{2}{*}{$\begin{array}{c}\text { Specific } \\
\text { activity } \\
\left(\mathrm{U} \mathrm{mg}^{-1}\right)\end{array}$} \\
\hline Reagent & $\mathrm{pH}$ & & & & & & \\
\hline $\mathrm{NaPO}_{4}$ & $6 \cdot 0$ & 0.05 & $0 \cdot 1$ & NM & & & \\
\hline $\mathrm{NaNO}_{2}$ & $6 \cdot 0$ & & & & 0.05 & 0.2 & NM \\
\hline UME & $8 \cdot 3$ & $0 \cdot 12$ & 0.4 & $2 \cdot 9$ & 0.28 & 0.1 & NM \\
\hline DTT & $8 \cdot 3$ & 0.30 & 0.6 & 1.8 & 0.32 & 0.1 & NM \\
\hline $\mathrm{U}$ & $3 \cdot 0$ & 0.15 & 1.7 & 11 & 0.17 & $2 \cdot 8$ & 16 \\
\hline G & $3 \cdot 0$ & 0.05 & 0.4 & NM & 0.05 & 0.1 & NM \\
\hline $\mathrm{ME}$ & $3 \cdot 0$ & 0.47 & 140 & 290 & 0.15 & $0 \cdot 1$ & NM \\
\hline UME & $3 \cdot 0$ & 1.00 & 170 & 170 & $1 \cdot 10$ & 320 & 290 \\
\hline GME & $3 \cdot 0$ & 0.06 & 0.9 & 15 & 0.67 & 68 & 100 \\
\hline DTT & 3.0 & $0 \cdot 16$ & $4 \cdot 3$ & 27 & 0.19 & 0.1 & NM \\
\hline
\end{tabular}

\title{
RESULTS AND DISCUSSION
}

\section{Extraction of spore-lytic enzyme (SLE)}

Non-germinated spores and nitrite-germinated spores (N-germinated spores) were extracted with sodium phosphate, sodium nitrite and reagents known to extract spore coat protein (Table 1). Detectable SLE activity was found in all extracts of non-germinated spores, with acidic urea/mercaptoethanol (UME) and mercaptoethanol (ME) extractions yielding the highest specific activity (170 and $290 \mathrm{U} \mathrm{mg}^{-1}$, respectively). Extraction of non-germinated spores with dithiothreitol/sodium dodecyl sulphate, $\mathrm{pH}$ 10.0, did not yield detectable activity (data not shown).

Extraction of $\mathrm{N}$-germinated spores failed to yield significant enzyme activity except with acidic UME and guanidine/mercaptoethanol (GME). The specific activity obtained using acidic UME ( $290 \mathrm{U} \mathrm{mg}^{-1}$ ) was comparable with that obtained when non-germinated spores were extracted with acidic ME, but the SLE activity extracted from the $\mathrm{N}$-germinated spores was more than twice that obtained from the non-germinated spores $\left(320\right.$ versus $\left.140 \mathrm{U} \mathrm{ml}^{-1}\right)$. No enzyme activity was detected in the supernatant fluid of heated $\left(75^{\circ} \mathrm{C}, 15 \mathrm{~min}\right)$, intact spores or $\mathrm{N}$-germinated spores.

The surprisingly high SLE activity obtained from $\mathrm{N}$-germinated spores prompted an investigation into the extraction of spores germinated by means other than nitrite. These germinants were $\mathrm{KCl}$ (Ando, 1979) and a 'complex germinant' (CG). Like nitrite, both of these germinants led to rapid germination without observable outgrowth. However, unlike the supernatant fluid from $\mathrm{N}$-germinated or non-germinated spores, the germination exudates with these germinants had significant levels of SLE activity (94 and $11 \mathrm{U} \mathrm{ml}^{-1}$ for CG- and $\mathrm{K}$-germinated spores, respectively; Table 2). Spores germinated in these media yielded significant SLE activity only when extracted with acidic ME, U and UME. The latter extracted the highest concentration of SLE regardless of the method of germination. As in the case of $\mathrm{N}$-germinated spores, extraction of $\mathrm{CG}$ - or $\mathrm{K}$-germinated spores with alkaline reagents did not yield significant levels of active SLE, nor did extraction with DTT, pH 3.0. 
Table 2. Extraction of spore-lytic enzyme from $C G$-and $K$-germinated spores of $C$. perfringens

Clean spores were heated $\left(75^{\circ} \mathrm{C}, 15 \mathrm{~min}\right)$ and germinated in either complex germinant $(\mathrm{CG})$ or potassium chloride (K) as described in Methods. Extraction conditions and reagents were as in Table 1. Four K-germinated spore pellets were collected after extraction and each was re-extracted in UME, pH 3.0, for $120 \mathrm{~min}$. Both the re-extracted material and the initial extracts were treated identically.

\begin{tabular}{|c|c|c|c|c|c|c|c|c|c|c|}
\hline \multirow{2}{*}{\multicolumn{2}{|c|}{$\begin{array}{c}\begin{array}{l}\text { Extraction } \\
\text { procedure }\end{array} \\
\end{array}$}} & \multicolumn{3}{|c|}{ CG-germinated spores } & \multicolumn{3}{|c|}{ K-germinated spores } & \multicolumn{3}{|c|}{$\begin{array}{c}\mathrm{Re} \text {-extracted } \\
\mathrm{K} \text {-germinated spores }\end{array}$} \\
\hline & & $\begin{array}{c}\text { Protein } \\
\left(\mathrm{mg} \mathrm{ml}^{-1}\right)\end{array}$ & $\begin{array}{l}\text { Activity } \\
\left(\mathrm{U} \mathrm{ml}^{-1}\right)\end{array}$ & $\begin{array}{c}\text { Specific } \\
\text { activity } \\
\left(\mathrm{U} \mathrm{mg}^{-1}\right)\end{array}$ & $\begin{array}{c}\text { Protein } \\
\left(\mathrm{mg} \mathrm{ml}^{-1}\right)\end{array}$ & $\begin{array}{l}\text { Activity } \\
\left(\mathrm{U} \mathrm{ml}^{-1}\right)\end{array}$ & $\begin{array}{c}\text { Specific } \\
\text { activity } \\
\left(\mathrm{U} \mathrm{mg}^{-1}\right)\end{array}$ & $\begin{array}{c}\text { Protein } \\
\left(\mathrm{mg} \mathrm{ml}^{-1}\right)\end{array}$ & $\begin{array}{l}\text { Activity } \\
\left(\mathrm{U} \mathrm{ml}^{-1}\right)\end{array}$ & $\begin{array}{c}\text { Specific } \\
\text { activity } \\
\left(\mathrm{U} \mathrm{mg}^{-1}\right)\end{array}$ \\
\hline CG & $7 \cdot 0$ & 0.08 & 94 & 1200 & & & & & & \\
\hline $\mathbf{K}$ & $7 \cdot 0$ & & & & NM & 11 & NM & & & \\
\hline ME & $8 \cdot 5$ & 0.38 & 0.2 & $<1$ & 0.41 & 0.2 & 0.5 & & & \\
\hline UME & $8 \cdot 5$ & 0.63 & $<0 \cdot 1$ & $<1$ & 0.98 & $<0.1$ & $<1$ & 0.08 & 47 & 600 \\
\hline DTT & 8.5 & 0.49 & $1 \cdot 0$ & 2 & 0.68 & 0.5 & 1 & & & \\
\hline $\mathrm{U}$ & $3 \cdot 0$ & 0.06 & 22 & 370 & $0 \cdot 10$ & 58 & 580 & & & \\
\hline $\mathrm{G}$ & 3.0 & 0.12 & $2 \cdot 0$ & 17 & 0.11 & NT & NM & & & \\
\hline ME & $3 \cdot 0$ & 0.13 & 72 & 550 & $0 \cdot 10$ & 130 & 1300 & 0.11 & 300 & 2700 \\
\hline UME & $3 \cdot 0$ & 0.23 & 110 & 470 & 0.16 & 300 & 1900 & 0.41 & 68 & 170 \\
\hline GME & 3.0 & 0.11 & $1 \cdot 0$ & 9 & 0.09 & 0.5 & 6 & 0.32 & 200 & 630 \\
\hline DTT & $3 \cdot 0$ & NM & 0.2 & NM & 0.04 & 0.9 & 20 & & & \\
\hline
\end{tabular}

NM, Not measurable; NT, not tested.

Alkaline UME treatment of $\mathrm{K}$-germinated spores produced about fivefold more protein than acidic UME treatment $\left(0.98\right.$ versus $\left.0.16 \mathrm{mg} \mathrm{ml}^{-1}\right)$. When both such treated spores were re-extracted with acidic UME, those spores which had originally been extracted with acidic UME continued to release both protein and active SLE, although at a much lower total activity than obtained during the first extraction (68 versus $300 \mathrm{U} \mathrm{ml}^{-1}$ ). Those spores which had previously been extracted with alkaline UME did not release much more protein upon re-extraction $\left(0.08\right.$ versus $\left.0.98 \mathrm{mg} \mathrm{ml}^{-1}\right)$ but did release more enzyme (47 versus $<0.1 \mathrm{U}$ $\mathrm{ml}^{-1}$ ), i.e. about the same as that released by re-extraction of spores originally extracted with acidic UME. If alkaline UME had been unable to extract SLE specifically, then high levels of SLE might have been expected upon re-extraction with acidic UME. As this was not the case, it is likely that, although effective in solubilizing spore proteins, alkali solubilizes SLE in an irreversibly inactive form. Acidic UME re-extraction of spores previously extracted with acidic ME and GME indicated that a substantial amount of active enzyme remained in the spore after the initial extraction with these reagents. Consequently, as with non-germinated or $\mathrm{N}$-germinated spores, acidic UME was the best of the reagents tested for extraction of active SLE. SLE extracted by UME hydrolysed isolated cortical fragments of strain 8798 (data not shown).

Brown et al. (1978) reported that extraction of $B$. cereus with acidic UME produced inconsistent levels of SLE, while GME worked well. We found the contrary to be true for $C$. perfringens. Acidic UME extraction of $\mathrm{N}$-germinated spores yielded a continuous increase in active SLE solubilized during $120 \mathrm{~min}$, while GME extracts, first assayed at $60 \mathrm{~min}$, showed a $40 \%$ loss of SLE activity by 120 min (data not shown). Unlike UME extractions, GME extractions were very dependent on the ratio of reagent to spores, losing activity more rapidly at greater dilutions. For example, $\mathrm{N}$-germinated spores $\left(7 \times 10^{9}\right)$ extracted in $8.0 \mathrm{ml} \mathrm{GME}$ for 60 min yielded only $56 \%$ of the active SLE obtained when the same number of spores were extracted in $4.0 \mathrm{ml}$ GME. Further, SLE activity in the more dilute system decreased $80 \%$ by 120 min.

The loss of activity upon prolonged extraction of spores in GME was not surprising, since this compound is an active protein denaturant. Urea acts in the same way yet, for some 
reason, did not irreversibly inactivate SLE. These reagents probably act by peeling away layers of spore coat after disulphide cross-links, which secure the coat structure, are broken by mercaptoethanol. It is not known if SLE remained active during extraction, or was denatured by UME and renatured during dialysis. UME extracts assayed before dialysis did not display any activity, but since SLE activity is sharply inhibited by high ionic strength (D. E. Gombas \& R. G. Labbe, unpublished data) it was not possible to distinguish between these possibilities.

\section{Effect of $p H$ on extraction of SLE}

It was apparent that, of the methods tested, acidic UME yielded the highest activity of SLE. This was true for both non-germinated and germinated spores. UME has been used by a number of researchers for extracting spore coats, and the importance of $\mathrm{pH}$ was demonstrated by Gould \& Hitchins (1963). We therefore examined the effect of the initial pH on extraction of protein and enzyme activity from $\mathrm{N}$-germinated spores. The $\mathrm{pH}$ of UME was found to be critical in the extraction of SLE. The highest SLE activities were extracted at $\mathrm{pH}$ values of 2.7 and 3.0 (data not shown). At $\mathrm{pH}$ values below 2.3 or above 3.5 , both extractable activity and protein dropped off dramatically $(10 \%$ and $<0.5 \%$ of optimum activity, respectively). Gould \& Hitchins (1963) have reported this sharp pH range for extraction of spore coat material in $B$. cereus. They suggested that it might be because spores are reported to have a net zero charge around $\mathrm{pH} 3$, and that this could influence the accessibility or reactivity of spore coat disulphide bonds. Brown et al. (1977) have suggested that this $\mathrm{pH}$ range is effective because mercaptoethanol is most effective as a reducing agent around $\mathrm{pH} 3$. A starting $\mathrm{pH}$ of 2.85 was selected for all further studies.

\section{Influence of the sulphydryl reagent on extraction of $S L E$}

Urea $(7.2 \mathrm{M})$ was included with $1.3 \mathrm{M}$-DTT or $1.3 \mathrm{M}$-sodium thioglycollate or $2.6 \mathrm{M}$ (20\%) ME, and each was compared with $7.2 \mathrm{M}$-urea plus $1.3 \mathrm{M}(10 \%) \mathrm{ME}$ (UME) for their ability to extract protein and SLE from $\mathrm{N}$-germinated spores. Increasing the concentration of ME did not significantly affect the amount of protein or SLE extracted (data not shown). Similar levels of protein and enzyme activity were obtained when urea plus DTT was used in place of UME.

The importance of the sulphydryl reagent is not yet clear. Although acidic ME alone was capable of extracting significant amounts of SLE, DTT was not. When coupled with urea, both sulphydryl reagents responded synergistically, and with equal efficiency. However, urea plus thioglycollate, $\mathrm{pH} 2 \cdot 85$, was incapable of extracting active SLE, or significant amounts of protein.

\section{Release of SLE during germination}

As previously mentioned, after germination with $\mathrm{KCl}$ or $\mathrm{CG}$, a significant level of SLE activity was detected in the exudate. Figure 1 shows the kinetics of release of this activity from spores germinated with $\mathrm{KCl}, \mathrm{NaNO}_{2}$ or $\mathrm{CG}$. Microscopic examination at each sampling time showed that greater than $95 \%$ of $\mathrm{KCl}$ - and $\mathrm{NaNO}_{2}$-treated spores had germinated within 30 and $45 \mathrm{~min}$, respectively. However, only $60 \mathrm{U} \mathrm{ml}^{-1}$ was released by germination with $\mathrm{KCl}$ and none with $\mathrm{NaNO}_{2}$. No SLE activity was detected following incubation of heat-shocked or unheated spores (non-germinated) in sodium phosphate buffer (data not shown). Although the initial rate of SLE release and phase-darkening in CG occurred more slowly than in $\mathrm{KCl}$, the final activity approached 40 times that of the $\mathrm{K}$-germinated spores. The presence of chloramphenicol did not significantly affect the levels of SLE released by spores germinated in CG, but did prevent spore outgrowth (data not shown). As with UME extracts, the $\mathrm{KCl}$ exudate and the $\mathrm{CG}$ exudate were active in hydrolysing cortical fragments. These preparations were not characterized further. 


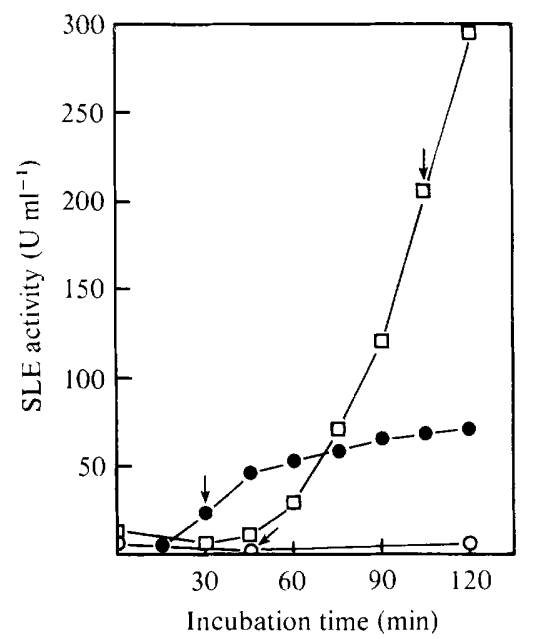

Fig. 1. Release of SLE in exudate during germination of $C$. perfringens spores. Clean spores were heated $\left(75^{\circ} \mathrm{C}, 15 \mathrm{~min}\right)$ and germinated at $45^{\circ} \mathrm{C}$ with sodium nitrite $(\mathrm{O})$, potassium chloride $(\mathrm{O})$ or complex germinant $(\square)$ as described in Methods. At intervals, samples were centrifuged and the supernatants were assayed for SLE activity without prior dialysis. Arrows indicate the times at which at least $95 \%$ of spores were phase-dark.

Since SLE, present in the germination exudates of $\mathrm{K}$ - and CG-germinated spores, was absent from the supernatant of $\mathrm{N}$-germinated spores, some relevant properties of $\mathrm{NaNO}_{2}$ were explored. It was possible that $\mathrm{NaNO}_{2}$ might inactivate SLE during germination. However, SLE did not lose any activity upon holding for up to $1 \mathrm{~h}$ in $\mathrm{NaNO}_{2}, \mathrm{pH} 6 \cdot 0$, at concentrations as high as $160 \mathrm{~mm}$ (final nitrite concentration during SLE assay was $32 \mathrm{~mm}$ ). Ando (personal communication) has suggested that nitrite will non-enzymically hydrolyse spore peptidoglycan at $\mathrm{pH} 4.0$. We tested this in our system by incubating cortical fragments

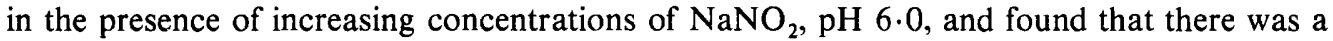
significant increase in the rate of turbidity decrease with $\mathrm{NaNO}_{2}$ at concentrations above 50 mM. In assay spore suspensions with $200 \mathrm{mM}-\mathrm{NaNO}_{2}$, turbidity decreased at a rate of $7.4 \times$ $10^{-3} A_{600}$ units $\mathrm{min}^{-1}$; this was 16 times faster than in the absence of $\mathrm{NaNO}_{2}$. When incubated in $200 \mathrm{~mm}-\mathrm{KNO}_{2}$, cortical fragments and assay spores both showed similar rates of decrease in turbidity to those observed with $\mathrm{NaNO}_{2}$, but neither cortical fragments nor assay spores showed a significant decrease in turbidity when incubated in $200 \mathrm{mM} \mathrm{NaCl}$ or $\mathrm{KCl}$ (data not shown). Further, $\mathrm{NaNO}_{2}$ had a 10 -fold higher spore-lytic activity at pH 6.0 than at $\mathrm{pH} 8.0$ (data not shown), indicating the protonated form of nitrite was the active agent. Our results therefore support Ando's findings, i.e. that nitrite, or nitrous acid, will non-enzymically lyse spore cortex, and thereby cause spores to germinate.

With this system, it is clear that germination, by itself, is necessary but not sufficient for release of SLE from the spore. The latter requires a release mechanism which seems to be satisfied by $\mathrm{CG}$, only partially satisfied by $\mathrm{KCl}$ and not satisfied by $\mathrm{NaNO}_{2}$ at all.

Germination with CG most closely approaches germination of spores in typical $C$. perfringens growth media. Therefore, gradual release of SLE during germination would be expected to aid in the germination of nearby spores which are deficient in this enzyme, or injured, e.g. by heat, but permeable enough to accept the enzyme. This could explain the presence of 'secondary' or satellite colonies which frequently appear on plates of heat-injured C. perfringens spores after prolonged incubation (Cassier \& Ryter, 1971).

\section{Kinetics of release of SLE by UME}

As shown in Tables 1 and 2, the highest SLE extraction was obtained by extracting spores using acidic UME. However, it was not directly clear whether these conditions affected the 

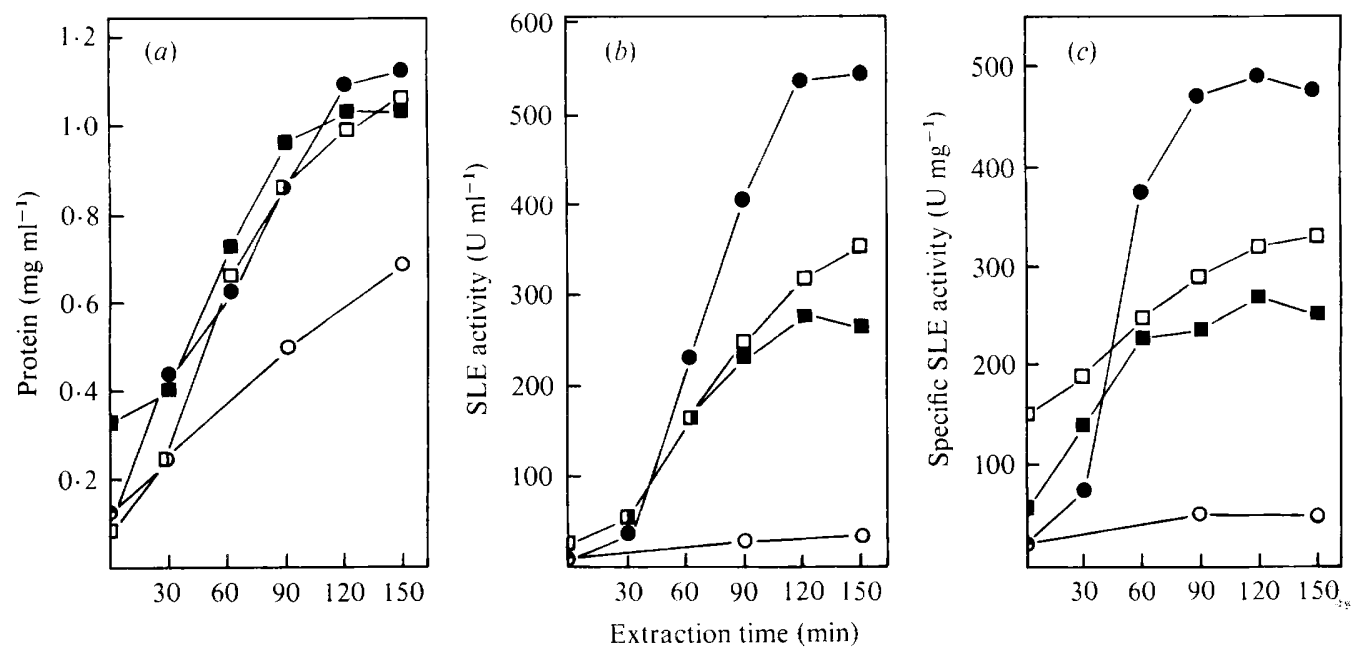

Fig. 2. Kinetics of release of SLE during UME extraction of $C$. perfringens spores. Clean spores were heated $\left(75^{\circ} \mathrm{C}, 15 \mathrm{~min}\right)$ and either 'non-germinated' $(\mathrm{O})$, or germinated with sodium nitrite $(\boldsymbol{O})$, potassium chloride $(\square)$ or complex germinant ( $\square$ ), as described in Methods, until at least $95 \%$ of spores were phase-dark. Spores were washed once in cold distilled water, and extracted with UME, pH 2.85 , at $45^{\circ} \mathrm{C}$. Samples were dialysed overnight before assaying for protein $(a)$, SLE activity $(b)$, or specific SLE activity $(c)$.

quantity of active SLE extractable by UME. The kinetics of release of protein and SLE from non-germinated and $\mathrm{N}$-, $\mathrm{K}$ - and CG-germinated spores are shown in Fig. 2. Germination was required for maximum protein extraction (Fig. $2 a$ ), but the germinant used did not significantly affect either the rate or extent of protein extraction. However, the germinant used did significantly affect the total activity extracted. The greatest amount of SLE, expressed as $\mathrm{U} \mathrm{ml}^{-1}$ or $\mathrm{U} \mathrm{mg}^{-1}$, which could be extracted with UME was obtained from spores germinated with nitrite. K- and CG-germinated spores yielded less activity (Fig. 2b,c). While UME was capable of extracting protein from the non-germinated spores at about half the rate of germinated spores, extraction of active SLE was even more retarded, resulting in a maximum specific activity only $10 \%$ of that obtained from $\mathrm{N}$-germinated spores in $2 \mathrm{~h}$.

Both Gould et al. (1966) and Ando (1979) have suggested that germination is a necessary step for maximum release of SLE from spores. Results presented here support this observation, as extraction of non-germinated spores yielded far less protein and active enzyme. The reason for this is not known. Although Gould et al. (1966) could not obtain evidence that this is due to activation of zymogens, they suggested it might be due to release of the enzyme from a bound form. Release of SLE in the presence of chloramphenicol suggests that de novo synthesis during germination is not responsible for the disparity in active enzyme levels. This is further supported by the results of Cleveland \& Gilvarg (1975), who found that spores of $B$. megaterium lys mutants were equally capable of germination in the presence or absence of exogenous lysine. Further, UME extraction of vegetative cells prepared in Fluid Thioglycollate Medium, a glucose-rich asporogenic growth medium, did not yield detectable activity (data not shown), indicating that extractable SLE is not a product of vegetative cell metabolism.

It is not yet possible to say that the SLE released from the spore during germination is the same protein as the SLE extracted by UME. Indeed, Warth (1972) identified four separate cortex-degrading activities in spores of $B$. cereus. However, it is interesting to note that, although the differences are not stoichiometric, the germinated spores which exude the least amount of SLE, i.e. N-germinated spores, yield the greatest concentration of SLE upon UME extraction, and that the converse is also true. 
This work was supported by the U.S. Army Research Office and by Experiment Station Project no. 484.

\section{REFERENCES}

ANDo, Y. (1979). Spore lytic enzyme released from Clostridium perfringens spores during germination. Journal of Bacteriology 140, 59-64.

Aronson, A. I. \& Fitz-James, P. C. (1976). Structure and morphogenesis of the bacterial spore coat. Bacteriological Reviews 40, 360-402.

BRADFORD, M. M. (1976). A rapid and sensitive method for the quantitation of microgram quantities of protein utilizing the principle of protein-dye binding. Analytical Biochemistry 72, 248-254.

Brown, W. C. \& Cuhel, R. L. (1975). Surfacelocalized cortex-lytic enzyme in spores of Bacillus cereus T. Journal of General Microbiology 91, $429-432$.

Brown, W. C., Cuhel, R. L. \& Greer, C. (1977). Isolation and properties of a surface-bound cortexlytic enzyme from spores of Bacillus cereus $\mathrm{T}$. In Spore Research 1976, pp. 335-349. Edited by A. Barker, L. Wolf, D. J. Ellar, G. J. Dring \& G. W. Gould. London: Academic Press.

Brown, W. C., Vellom, D., Schnepf, E. \& Greer, C. (1978). Purification of a surface-bound hexosaminidase from spores of Bacillus cereus T. FEMS Microbiology Letters 3, 247-251.

Cassier, M. \& Ryter, A. (1971). Sur un mutant de Clostridium perfringens donnant des spores sans tuniques a germination lysozyme-dépendante. Annales de l'Institut Pasteur 117, 312-324.

Cleveland, E. F. \& Gilvarg, C. (1975). Selective degradation of peptidoglycan from Bacillus megaterium spores. In Spores VI, pp. 458-464. Edited by P. Gerhardt, R. N. Costilow \& H. L. Sadoff. Washington, D.C.: American Society for Microbiology.

DunCAN, C. L., LABbE, R. G. \& Reich, R. R. (1972). Germination of heat- and alkali-altered spores of Clostridium perfringens type $\mathrm{A}$ by lysozyme and an initiation protein. Journal of Bacteriology 109, 550-559.

Franceschini, T. J. \& LabBe, R. G. (1979). Sensi- tivity of chemically treated spores of Clostridium perfringens type $\mathrm{A}$ to an initiation protein. Microbios 25, 85-91.

Gould, G. W. \& Hitchins, A. D. (1963). Sensitization of bacterial spores to lysozyme and to hydrogen peroxide with agents which rupture disulphide bonds. Journal of General Microbiology 33, 413423.

Gould, G. W., Hitchins, A. D. \& King, W. L. (1966). Function and location of a 'germination enzyme' in spores of Bacillus cereus. Journal of General Microbiology 44, 293-302.

Hashimoto, T., Frieben, W. \& Conti, S. (1972). Kinetics of germination of heat-injured Bacillus cereus spores. In Spores V, pp. 409-415. Edited by H. O. Halvorson, R. Hanson \& L. L. Campbell. Washington, D.C.: American Society for Microbiology.

Labbe, R. G., Reich, R. R. \& DunCan, C. L. (1978). Alteration in ultrastructure and germination of Clostridium perfringens type A spores following extraction of spore coats. Canadian Journal of Microbiology 24, 1526-1536.

Powell, J. F. \& Strange, R. E. (1953). Biochemical changes occurring during germination of bacterial spores. Biochemical Journal 54, 205-209.

Strange, R. \& DaRK, F. (1957). A cell-wall lytic enzyme associated with spores of Bacillus species. Journal of General Microbiology 16, 236-249.

VARY, J. C. (1973). Germination of Bacillus megaterium spores after various extraction procedures. Journal of Bacteriology 116, 797-802.

WARTH, A. (1972). Action of spore lytic enzymes on the cortex. In Spores V, pp. 28-34. Edited by H. O. Halvorson, R. Hanson \& L. L. Campbell. Washington, D.C.: American Society for Microbiology.

WyatT, L. \& Waites, W. M. (1974). The effect of sodium hydroxide or dithiothreitol-urea on spores of germination mutants of Clostridium bifermentans. Journal of General Microbiology 84, 391-394. 